\title{
Multilingualism in Kosovo and Switzerland; a Comparable Viewpoint of Language Policy
}

\section{Bardha Gashi}

\author{
PhD candidate, New Bulgarian University,Sofia, Bulgaria
}

\begin{abstract}
The main aim of the paper is to show the differences and similarities of the language use and language policy in The Republic of Kosovo and The Federation of Switzerland. It has a look in to the core documents of language including the constitution of both countries.
\end{abstract}

Keywords: multilingualism, Kosovo, Switzerland, language use, language policy

\section{Introduction}

Despite the small territorial surface and the population both countries are officially multilingual. Kosovo officially recognizes two languages on the national level; Albanian spoken by $95 \%$ of the population and Serbian spoken by $3 \%$ of the population, and two other on the municipal level; Bosnian and Turkish together spoken by $2 \%$ of the population. Whereas, Switzerland has four national languages. It is German which is a language spoken by a majority of the population $63.6 \%$, French spoken by $19.2 \%$ Italian $7.6 \%$ and Romansh spoken by $0.6 \%$. Both countries have different historical backgrounds and events that have had an impact on the countries to become multilingual nations. Kosovo has a central position in the Balkans, bordering with Albania in the South, Macedonia in the East, Serbia in the North and Montenegro in the Northwest. This crossroad position in the Balkans has had an impact on language situation as well as intercultural environment and relationship among ethnicities, which have changed from time to time. A history snapshot of six centuries would be: five centuries under Ottoman Empire, a century part of Serbia and Yugoslavia and around 20 years "a country of its own". Without doubt these are the key factors in actual religious, ethnic, cultural and language situation in Kosovo. As broadly known three original so called cantons joined together to create a union in order to defend themselves of surrounding countries known today as: Austria, France, Italy and Germany.

\section{Language Policy and Arrangement}

Language rights and the use of language have always been an issue around the globe and have been explored and treated by many researchers and publishers as an important and the most sensitive element of identity, especially when it comes to language rights of minorities. These topics are even more current in the Balkans, a region known for multilingualism and multiculturalism. The region of the Balkans is widely known for its diverse cultural and language lands=cape. Nevertheless, there might be clear territorial separations of languages all of the countries of the Balkans Peninsula are multilingual, as the case is with the Republic of Kosovo. People have learned languages here in order to fulfill daily obligations, to prosper and integrate. Prof Sadik Idrizi describes the language issue in the Balkans as follows:

It is common in the Balkans that people speak many languages and are in contact with communities of different language groups. They often try to use a prestige language, depending on the country they live in, the country that ruled in a certain period in history. (Idrizi, Jezik i stil narodne poezije Gore, 2012)

The Republic of Kosovo as a young democratic country declared its independence on February 17, 2008, and so far has been recognized by the majority of United Nations Member states (114 until this paper was published). Since 1999, immediately after the last armed conflict many things have changed including the language legislation. As a multilingual and multicultural country, it seems to have defined very well the language issue and treated it very neatly in legislation on language. It is clear that the national identities have been taken into consideration when drafting the language policy and language rights as a main mean of identification. 
Languages serve as a means of identification, as important ethnic symbols, therefore they are close related to emotions and subjective value judgements, which is why they easily become signs of national anticipation but also objects of nationalist manipulation. (Bugarski, 2007)

Language rights in Kosovo and Switzerland are guaranteed and protected by the highest juridical act which is the Constitution of the country, In the case of Kosovo it is clearly defined, whereas, in Switzerland it is the issue of the local authorities.

Language rights and use of language are defined by many core legislation documents of the Republic of Kosovo. Article 5 of the Constitution defines Albanian and Serbian language as the official languages in the country on national level. Bosnian and Turkish languages are defined as official languages in municipalities as provided by law.

\subsection{The official languages in the RK are Albanian and Serbian.}

5.2. Turkish, Bosnian and Roma languages have the status of official languages at the Municipal level or will be in official use at all levels as provided by law. (Constitution of the Republic of Kosovo, 2008)

Multilingualism in Switzerland is also guaranteed by the highest juridical act, The Constitution of the Swiss Federation.

Art. 4 National languages

The National Languages are German, French, Italian, and Romansh. (Federal Constitution of The Swiss Federation)

\section{Art. 70 Languages}

1 The official languages of the Confederation are German, French and Italian. Romansh is also an official language of the Confederation when communicating with persons who speak Romansh.

2 The Cantons shall decide on their official languages. In order to preserve harmony between linguistic communities, the Cantons shall respect the traditional territorial distribution of languages and take account of indigenous linguistic minorities.

3 The Confederation and the Cantons shall encourage understanding and exchange between the linguistic communities. (Federal Constitution of The Swiss Federation)

The language situation in Switzerland seems to have come in more natural and logically explainable way. Compared to Kosovo, in Switzerland languages are divided based on territorial inhabited areas, known as cantons. The overall language legislation has a very careful treatment to all national languages and it has a conservational approach.

The Cantons shall designate their official languages. In order to preserve harmony between linguistic communities, they shall respect the traditional territorial distribution of languages, and take into account indigenous linguistic minorities." (Federal Constitution of The Swiss Federation)

Kosovo and Switzerland seem to have very different state organizations in terms of government and regional.

There are six constitutional entities in Kosovo and two official languages on the state level. In the research paper we focus mainly on central institutions when talking about general situation of official languages in Kosovo. When analyzing language use on the local level, city of Prizren is taken as an example of multilingualism, multiculturalism, as a city of mutual tolerance and harmony.

Different from Kosovo, where language issue is the case of the central government, in Switzerland language issue is the case of the local government.

Switzerland is a federation made up by different localities known as cantons. As a result of federalism, certain powers are assigned to the federal government while others are assigned to the localities.

For the most part, policymaking power is devolved to the cantons. Such is the case with language and education policies. Because these powers have been delegated to local officials, practices can vary from region to region so long as they are in compliance with federal laws. What stems from this devolution is the principle of "territoriality." (Morrison, 2013). 
Article 29.2 guarantees everyone to be informed in mother tongue in the case of deprived liberty. According to article 59.3 everyone has the right to obtain primary and secondary education in his mother tongue. Article 59.6 regulates the use of language on municipal level. It guarantees to non-majority communities the right to use their mother tongue where they represent sufficient share of the population in accordance with the law. In case of the use of translator costs are covered by competent authorities.

The Constitution of the RK also guarantees the representation of TV program in community languages in accordance with the law and international standards. It guarantees the community language use in all other types of media like newspapers, radio, or social media.

Law nr. 02/L-37 of the RK regulates the use of language in the country. The Law ensures the use of the Albanian and Serbian language as official languages on the national level as well as Turkish, Bosnian and Roma languages on the level of municipality. Article 2.2 and 2.3 specifies the language use on municipal level. Municipalities that are inhabited with more than $5 \%$ of the population of the certain minority population, language of this minority are represented as official. Such municipality is Prizren, which is located in the South of Kosovo, where except the Albanian language, Turkish and Bosnian are official languages as well.

On central level, official languages are represented equally. Central institutions are obliged to ensure translation in all official languages. Moreover, official meetings have simultaneous translations when necessary. All speakers can freely express in their mother tongue. Official documents are issued in all official languages. Moreover, they are issued in English. In cases of misunderstanding in translation, English language is taken as credible. Names of institution in all levels are written in all official languages, in municipalities they are written in community languages too.

On municipal level, all languages are represented equally including languages on national and local level in all fields of administration and institutions, in media, official documents, minutes of debates, all levels of education. The law guarantees attending primary and secondary education on mother tongue for everyone. Municipalities of Prizren, Peja, and Mitrovica offer study programs in all municipal languages for all levels of education,

Similar language policy is inclusive and balanced. In some cases there is a subtle difference of language use on central and local level. However, it has never a discrimination approach in any forms towards any of the ethnicities forming the federation.

\section{Conclusion}

Switzerland became a multilingual country as an urgent need for survival and existence while Kosovo as a newborn country in order to satisfy international requirements made positive discrimination towards language use and policy. Switzerland seems to have a right system on place in terms of language use and clearly there are no what so ever serious challenges. In Kosovo, even though there are still ethnic tensions and the armed conflict happened just twenty years ago, there is a very modern and inclusive language policy on power. However, there is still work to do in order that the situation on the field is at a satisfactory level. This situation is mainly due to lack of economic and human capacities.

\section{Bibliography}

[1] Assembly of Kosovo. (2008). Law No. 03/L-047 On the Protection and Promotion of the Rights of Communities and Their Members in Kosovo. Retrieved from http://www.kuvendikosoves.org/?cid=2,1

[2] Bugarski, R. (2007). Lingvistika u Primeni. Beograd: Čigo.

[3] Federal Constitution of The Swiss Federation. (n.d.). Retrieved from file:///C:/Users/Dell/Desktop/multilingualism\%20in\%20swiss/swiss\%20constitution.pdf

[4] Idrizi, S. (2012). Jezik i stil narodne poezije Gore. Prizren.

[5] Parilament of Kosovo. (2011). Law on Pre-University Education in the Republic of Kosovo. Retrieved from http://www.kuvendikosoves.org/?cid=2,1

[6] Parilament of the Republic of Kosovo. (2008). Constitution of the Republic of Kosovo. Retrieved from http://www.kuvendikosoves.org/?cid=2,1 


\title{
Piero Gobetti and his Writings on International Politics in the 1920s
}

\section{Francesca Somenzari}

\begin{abstract}
Università degli Studi di Torino Piero Gobetti (Turin 1901- Paris 1926) was not only one of the most important thinker and political writer of the Twentieth Century, but also one of the greatest organizers of culture: in his short life, he founded three journals (Energie Nove, Rivoluzione Liberale and II Baretti) and a publishing house (Piero Gobetti Editore). Within his prodigious intellectual activity (obviously against Mussolini and what he represented), there was also room for reflection on the international politics of the 1920s. Gobetti's attention to international politics was expressed first in Energie Nove and then in Rivoluzione Liberale, with projects of columns and unique numbers especially dedicated to some foreign countries ${ }^{1}$.
\end{abstract}

Keywords: Piero Gobetti, international politics

\section{Introduction}

The main focus of many of Gobetti's writings was the Versailles Conference together with the decisions it gave rise to: international issues were analyzed in the light of a perspective that explicitly rejects nationalism². As Gobetti stated: "Versailles not only is not a peace, but it excludes peace"3.

The writer's considerations and conclusions were strongly influenced by the thought of Gaetano Salvemini and- albeit to a lesser extent- seemed to refer to the Wilsonian teaching (despite the criticisms addressed to it at first).

\section{Gobetti and Russia: among history, ecstatic contemplation and Liberalism}

In Energie Nove (1918-1920) and Rivoluzione Liberale (1922-1925), Piero Gobetti wrote several essays on Russia and in particular on the 1917 Revolution; Language, Literature and Leninism were the three Ls sparking Gobetti's interest. Together with his wife, Ada, he began studying Russian with the aim of translating Andreiev's works ${ }^{4}$; but ultimately, it is the phenomenon of the Bolshevik revolution that motivated Gobetti's general passion for Russia.

In "Frammenti di estetismo politico" and "La Russia dei Soviet", Gobetti presented the Revolution as one of those mythical and unrepeatable events that history offers only rarely: for this reason it had to be contemplated rather than judged. As he reported:

The Russian Revolution is history, you must study it; it is a social phenomenon [...]. You have before you a world of constant progress, and you looked for the scheme in which to enclose it [...]. The Revolutions do not look at the past. They create and shape new realities. The government of Lenin

\footnotetext{
${ }^{1}$ Two issues of Rivoluzione Liberale were devoted to Germany and Great Britain, respectively in January and March-April 1924. Regarding France, see N. Bobbio, F.S. Nitti et al., Piero Gobetti e la Francia. Atti del colloquio italo-francese, Franco Angeli, Milano, 1985.

2 See F. Somenzari (edited by), Piero Gobetti. Vita internazionale, Aras, Fano, 2017, pp. 17-22.

3 P. Gobetti, II trionfo della democrazia, in "Rivoluzione Liberale" (from now on RL), II, n. 4, February 1st, 1923; the article is also included in P. Spriano (edited by), Scritti Politici, Einaudi, Torino, 1997, pp. 448-452.

Original text: "Versailles non solo non è una pace, ma esclude la pace".

${ }^{4}$ Gobetti defined Leonid Andreiev "the greatest of contemporary Russian writers". See P. Gobetti, Leonida Andreiev, in "Energie Nove" (from now on EN), II, n. 8, September 30, 1919.

Andreiev was defender of the revolution of 1905 and contrary to that of 1917, but above all he was against the excesses of Bolshevism.
} 
and Trotzki is a de facto government. It is the will of Russia. A state organization and not a scientific investigation. Life and not the book¹.

Gobetti stressed the importance of such a simple and fundamental concept: the Revolution is a fact and a new democracy is born. At first, he seemed to categorically reject any form of manipulation of the phenomenon, preferring a historical and objective interpretation to one of political expediency.

In Gobetti's writings, Lenin and Trozki were called great statesmen who elevated Russia to the level of Western civilizations, facing dangerous government responsabilities ${ }^{2}$. And then:

They [Lenin e Trotzki ] are not only Bolsheviks; they are the men of action who have awakened a people and are recreating a soul for them ${ }^{3}$.

The position taken by Gobetti led the communist Antonio Gramsci to write that Gobetti was a young men who had understood the greatness of the Revolution and its leaders"4.

However, after this first contemplation of the phenomenon of the Russian Revolution, in 1921 Gobetti denied himself, by stating:

Trotzki affirms a liberal ${ }^{5}$ view of history [...]. Only for tactical necessities and for historical needs, the Revolution- full of Liberalism, in a country like Russia, home of the mir, worshiper of every form of community- must take the name and sometimes the appearance of socialist work [...]. It is up to the historian to affirm the truth above political contingencies ${ }^{6}$.

From the ascertainment of the extraordinary nature of the Revolution and from a gaze that wanted to be as objective as possible, Gobetti moved on to an extremely partial political interpretation, placing the Russian events into the riverbed of the liberalism current. According to Gobetti, Trotzki carried on (without knowing it) a liberal, non-socialist design.

In this case, Gobetti's interpretation is neither shareable nor sustainable, but it is very interesting because it clearly demonstrates the non-systematic nature of his thinking ${ }^{7}$.

\section{Gobetti and the United States of America}

In Gobetti's writings even the United States were taken into consideration and not by chance: the First World War brought about the entry of the United States themselves into European life and dynamics, especially at the end of the conflict. Although in the 1920s President Harding carried on the motto America first - the basis of a highly isolationist policy - the Wilsonian conception of Europe and international relations was destined to have a lasting echo in the Old Continent, even

\footnotetext{
1 P. Gobetti, Frammenti di estetismo politico, in EN, II, n. 10, November 30, 1919; the article is also included in P. Spriano (edited by), Scritti Politici cit., pp. 206-213. Original text: "La Rivoluzione Russa è storia, voi dovete studiarla; è un fenomeno sociale [...]. Avete dinanzi un mondo in formazione, e voi cercato lo schema in cui rinchiuderlo [...]. Le Rivoluzioni (e tutta la storia del resto) non guardano il passato. Creano e plasmano nuove realtà. II governo di Lenin e Trotzki è un governo di fatto. E' la volontà della Russia. Un'organizzazione statale e non un'indagine scientifica. La vita e non il libro".

2 See P. Gobetti, La Russia dei Soviet, in "Volontà", February 15, 1921; the article is also included in P. Spriano (edited by), Scritti politici cit., pp. 197-206, p. 197.

3 P. Gobetti, Rassegna di questioni politiche, in EN, II, n. 6, July 25, 1919, pp. 132-139; the article is also included in P. Spriano (edited by), Scritti politici cit., p. 151. Original text: "Non sono solo dei bolscevichi, sono gli uomini d'azione che hanno destato un popolo e gli vanno ricreando un'anima".

${ }^{4}$ P. Gobetti, Paradosso sullo spirito russo, Einaudi, Torino, 1969, p. XXI.

5 In this case, the adjective "Liberal" has to be understood in its historical sense, that is "relative to the Liberal Party". Today the term "Liberal" is used with the meaning of "progressive".

${ }^{6}$ P. Gobetti, Trotzki, in "Il resto del Carlino», April 5, 1921; the article is also included in P. Spriano (edited by), Scritti Politici cit., pp. 206210. Original text: "Trotzki afferma una visione liberale della storia [...] Soltanto per necessità tattiche e per esigenze storiche quest'opera [la rivoluzione] feconda di liberalismo, in un paese come la Russia, patria del mir, adoratrice di ogni forma di comunità, deve prendere il nome e talvolta anche le apparenze di opera socialista [...]. Spetta allo storico affermare la verità al di sopra delle contingenze politiche". 7 See P. Polito, L'eresia di Piero Gobetti, Raineri Vivaldelli, Torino, 2018.
} 
by virtue of territorial changes which it produced at the Versailles Conference. The Fourteen Points and the birth of the League of Nations deeply engraved on the new European balance ${ }^{1}$.

In the above-mentioned journal "Energie Nove", Gobetti focused on Wilsonism and the League of Nations; the writer's judgment on this international organization (wanted by the Democratic President) was in some ways cautious and even a little suspicious: according to Gobetti, the League of Nations was characterized by excessive abstractness and a utopian vision that damaged its own work. So wrote Gobetti:

To correctly understand and evaluate everything that passes under the name of the League of Nations, we cannot stop at an examination of the potential abstract value of the idea, but we must immediately see its value in relation to social life, that is we must study in which practical forms it [the League] can be implemented ${ }^{2}$.

It was not only the idea itself relevant, but its practical implementation, its sustainability: "the politician feeds on reality".

The appeal to democracy as a pivot of peaceful coexistence and a guiding principle of international relations alone was not enough, beyond the morality that this internationalist project carried with it. On this point, Gobetti was very close to Salvemini's position.

Beyond the criticisms, in the pages of Gobetti there is however the recognition of the value of the New Diplomacy, that is of a vision that, in spite of its specific and contingent limits, will reveal itself in the long-term forward-looking.

A few years later, on the occasion of Wilson's death, Gobetti wrote:

To realize his greatness, the judgment must instead concern his American figure, in the history of America. His own election to the presidential seat is a solemn fact: as early as 1914 he had turmed out to be a great statesman. After the mediocrity of presidents like Taft or Roosevelt, the temper of a Lincoln emerges in Wilson ${ }^{3}$.

\section{References}

[1] E. Alessandrone Perona, Le provocazioni della ricerca, in "Passato e Presente", n. 97, 2016, pp. 103-120

[2] L. Beghin, Da Gobetti a Ginzburg. Diffusione e ricezione della cultura russa nella Torino del primo dopoguerra, Istituto storico belga di Roma, Roma-Bruxelles, 2007

[3] N. Bobbio, F.S. Nitti et al., Piero Gobetti e la Francia. Atti del colloquio italo-francese, Franco Angeli, Milano, 1985

[4] B. Bongiovanni, Da Marx alla catastrofe dei comunismi. Traiettorie e antinomie del socialismo, Unicopli, Milano, 2000

A. Cabella (edited by), Gobetti tra Riforma e rivoluzione, Franco Angeli, Milano, 1999

[5] M. Cattaruzza, L'Italia e la questione adriatica (1918-1926). Dibattiti parlamentari e panorama internazionale, II Mulino, Bologna, 2014

[6] J. B. Duroselle, Da Wilson a Roosevelt. La politica estera degli Stati Uniti dal 1913 al 1945, Cappelli, Bologna, 1963

\footnotetext{
1 It's essential to remember that, based on the principle of self-determination of peoples, the Austro-Hungarian Empire had disintegrated, giving rise to numerous national states; moreover, with respect to Italy, Wilson had taken a very tough position, denying it some strategic territories. See M. Cattaruzza, L'Italia e la questione adriatica (1918-1926). Dibattiti parlamentari e panorama internazionale, II Mulino, Bologna, 2014.

2 P. Gobetti, La Società delle Nazioni, in EN, I, n. 5, January 1-15, 1919; the article is also included in P. Spriano (edited by), Scritti Politici cit., pp. 65-67.

Original text: "Per intendere e valutare rettamente tutto ciò che passa sotto il nome di Società delle Nazioni, non ci possiamo fermare ad un esame del valore potenziale in astratto dell'idea, ma dobbiamo scendere subito a vederne il valore in relazione alla vita sociale, dobbiamo studiare cioè in quali forme pratiche essa si può attuare".

${ }^{3}$ P. Gobetti, Uomini e idee. Lo stile di Wilson, in RL, III, n. 7, February 12, 1924; the article is also included in P. Spriano (edited by), Scritti politici cit., pp. 591-593. Original text: "Per rendersi conto della sua grandezza il giudizio deve invece riguardare la sua figura di americano, nella storia dell'America. Già la sua elezione al seggio presidenziale è un fatto solenne: già nel 1914 si era rivelato un grande statista. Dopo la mediocrità di presidenti come Taft o Roosevelt, in Wilson si sente la tempra di un Lincoln".
} 
[7] L. Ginzburg, Gobetti e il significato della Rivoluzione Russa, in «Quaderni di giustizia e libertà», n. 5, dicembre 1932, pp. 88-92

[8] F.S. Nitti, La tragedia dell'Europa. Che farà l'America, Piero Gobetti Editore, Torino 1924

[9] F. S. Nitti, La Pace, Piero Gobetti Editore, Torino, 1925

[10] C. Panizza (edited by), L'autobiografia della nazione, Aras, Fano, 2016

[11] P. Polito, L'eresia di Piero Gobetti, Raineri Vivaldelli, Torino, 2018

[12] P. Polito, II liberalismo di Piero Gobetti, Centro Studi Piero Gobetti, Torino, 2006

[13] P. Polito, La rivoluzione russa come una rivoluzione liberale, in «Critica liberale», n. 225, vol. XXII, 2015, pp. 180-182

[14] G. Salvemini, Dal Patto di Londra alla Pace di Roma. Documenti della politica che non fu fatta, Torino, 1925

[15] G. Scroccu (edited by), Piero Gobetti. La "rigenerazione" dell'Italia e la politica del primo dopoguerra: gli anni di Energie Nove, Biblion, Milano, 2014

[16] F. Somenzari (edited by), Piero Gobetti. Vita internazionale, Aras, Fano, 2017

[17] F. Somenzari, Wilson, l'internazionalismo e la nuova diplomazia: un quadro complesso tra fallimento momentaneo e valore duraturo, in «Scienze e Ricerche», n. 24, marzo 2016, pp. 16-20

[18] P. Spriano (edited by), Scritti Politici, Einaudi, Torino, 1997 